\title{
Features of the geographical structure of the differential species of pine forests flora of the Russian Plain on the southern limit of the Pinus sylvestris L.
}

\author{
Nataliya O. Kin ${ }^{*}$ \\ ORCID: 0000-0002-2823-5739, \\ Institute of Steppe of the Ural Branch of the Russian Academy of Sciences, \\ 11 Pionerskaya Street, 460000 Orenburg, Russia
}

\begin{abstract}
Each flora is unique. To a greater extent this can be seen in the geographical structure of the differential species of the studied floras. The purpose of the work: to establish the geographical structure of the differential species of the pine forests of the Russian Plain on the southern border of the Pinus sylvestris area for identify the nature and uniqueness of these flora. To achieve the goal, a geographical characteristic has been established for the differential species floras of forest-steppe pine forests Oka-Don lowland: Usmansky and Khrenovsky, and floras of the steppe pine forests of the Trans Volga region: Buzuluksky and Krasnosamarsky. Considering the composition and structure of differential species, it was noted that the nature of each of the compared floras is best reflected in the geographical structure of the aborigine fraction of the floras. The following features were identified. Among the differential species of flora of the forest-steppe forests of the Oka-Don lowland, forest and forest-steppe species with a Holarctic and EuropeanWest Asian prevail. Among the differential species of pine forests of the steppe zone of the Trans Volga region, steppe species with a Eurasian and East European-Asian range predominate. Endemic species that were noted in the flora of the all studied pine forests give particular uniqueness.
\end{abstract}

Keywords: aborigine fraction, differential species, endemic species, forest-steppe and steppe zone, latitudinal and longitudinal groups, pine forests

\section{(C) 2020 Nataliya O. Kin}

This is an open access article distributed under the terms of the Creative Commons Attribution License (CC BY 4.0), which permits unrestricted use, distribution, and reproduction in any medium, provided the original author and source are credited.

Published by Ural Federal University and peer-reviewed under responsibility of BDI-2020

(III Russian National Conference "Information Technology in Biodiversity Research")

\section{Introduction}

One of the important points in comparative floristry is the identification of differential species that are found only in one of the compared floras (Kamelin 2017). These species determine the uniqueness and peculiarity of the flora. To a greater extent this can be seen in the geographical structure of the differential species of the studied floras. The purpose of the work: to establish the geographical structure of the differential species of the pine forests of the Russian Plain on the southern border of the Pinus sylvestris area for identify the nature and uniqueness of these flora.

\footnotetext{
* Corresponding author. E-mail address: kin_no@mail.ru
} 


\section{Materials and methods}

To identify differential species, we compared the pine forests floras of the Russian Plain at the southern limit of distribution of Pinus sylvestris L., in extreme climatic conditions for forest ecosystems in the steppe and forest-steppe zones (Fig. 1). Usmansky and Khrenovsky pine forests are located in the subzone of the typical foreststeppe of the Oka-Don lowland (hereinafter referred to as forest-steppe forests) (Milkov 1977). Khrenovsky pine forest - in the Voronezh Region, $75 \mathrm{~km}$ southeast of Usmansky pine forest, located on the border of Lipetsk and Voronezh. Buzuluksky and Krasnosamarsky pine forests are located in the steppe zone of the Trans-Volga region (hereinafter referred to as the steppe forests). Krasnosamarsky - in the southeast of the Samara region, connected by a narrow strip of forest (about $36 \mathrm{~km}$ long) along the right bank of the river Samara with the Buzuluksky pine forest, which develops on the border of two administrative regions, Samara and Orenburg (Godnev et al. 1949; Korchikov et al. 2010).

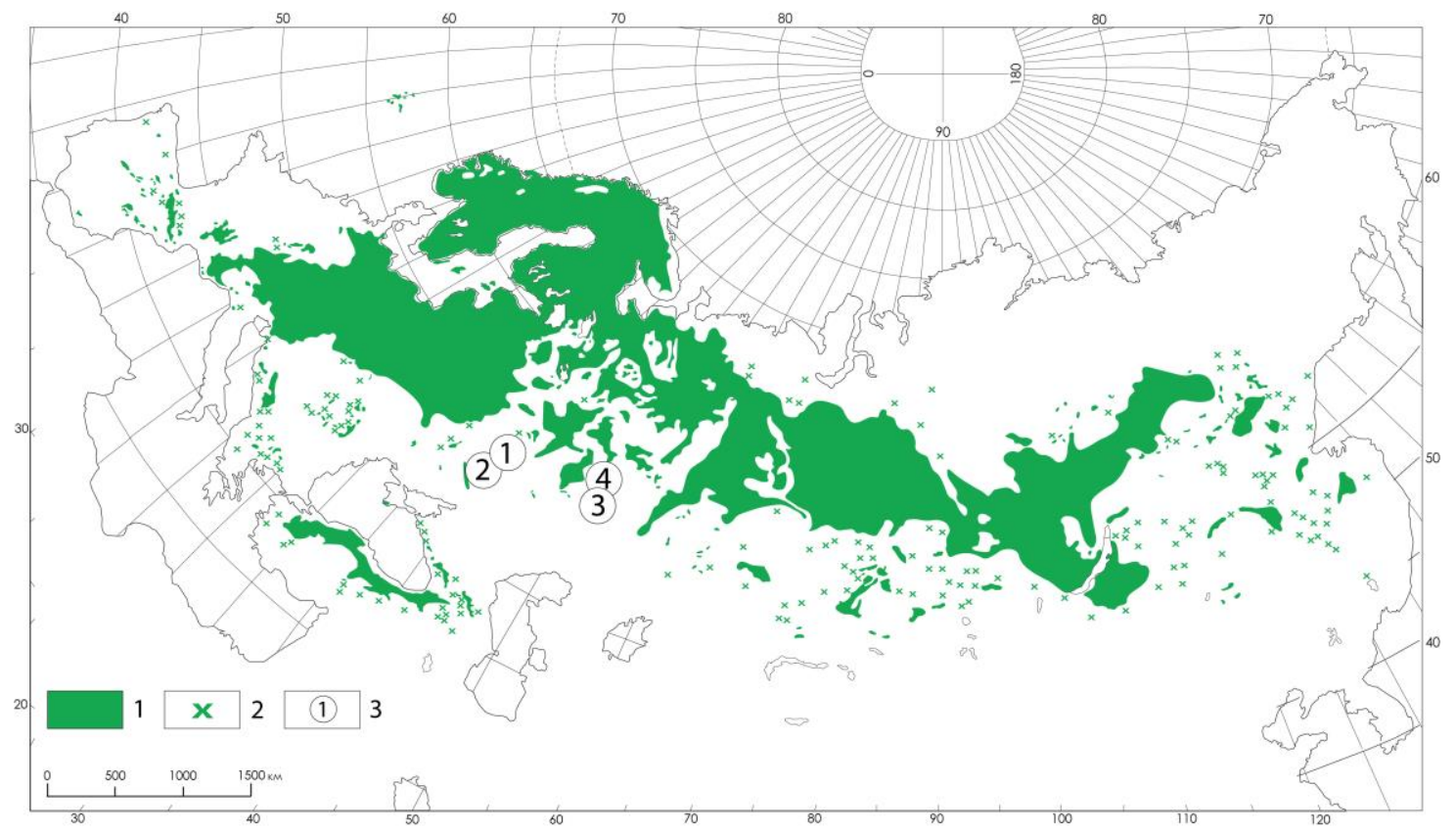

Figure 1. Map-diagram of the location of the studied of pine forests (Crichfield et al. (1966), as edited by the author).

Legend: 1 - range of the species; 2 - isolated occurrences; 3 - studied of pine forests

(1 - Usmansky, 2 - Khrenovsky, 3 - Buzuluksky, 4 - Krasnosamarsky).

The flora composition depends on the occupied area and the nature conservation status of the territory (Table 1).

Table 1. Territorial and environmental data of the studied pine forests.

\begin{tabular}{|l|c|c|l|c|}
\hline \multicolumn{1}{|c|}{ Pine forests } & $\begin{array}{c}\text { Area } \\
\text { (thousand ha) }\end{array}$ & $\begin{array}{c}\text { Natural and } \\
\text { climatic zone }\end{array}$ & $\begin{array}{c}\text { Conservation } \\
\text { status }\end{array}$ & $\begin{array}{c}\text { Year of } \\
\text { conferring } \\
\text { conservation } \\
\text { status }\end{array}$ \\
\hline Usmansky & 70.7 & \multirow{2}{*}{ forest-steppe } & $\begin{array}{l}\text { reserve on } \\
31053 \text { ha }\end{array}$ & 1927 \\
\cline { 5 - 6 } & 40.2 & & does not have & - \\
\hline Khrenovsky & 112.0 & \multirow{2}{*}{ steppe } & national park & 2007 \\
\cline { 1 - 1 } & 13.6 & & does not have & - \\
\hline Krasnosamarsky & & &
\end{tabular}


The floras of the studied pine forests were compared, as well as their aboriginal and adventive fractions (Kin 2019). Based on the data of A. Ya. Grigorievskaya et al. (2004), M.V. Kazakova et al. (1996), P.V. Kulikov et al. (2005, 2013), S.V. Saxonov et al. (2012), for each differential species latitudinal and longitudinal groups were established.

\section{Results}

In the course of floristic research, the taxonomic structure of the studied pine forests was established. In the flora of Usmansky pine forest, 123 families of 512 genera contain 1076 species, among which 848 are aboriginal, 216 are adventive and 8 are introduced species. In the flora of the Khrenovsky pine forest, 108 families of 430 genera unite 850 species, where 718 are from the aboriginal, 130 are the adventive fractions and 2 introduced species. The flora of the Buzuluksky pine forest is represented by 101 families, 282 genera, 794 species. The latter contain 675 species of aboriginal, 112 species of adventive fractions, and 4 introduced species. The flora of Krasnosamarsky pine forest includes 93 families of 352 genera 674 species, where most -591 - are aboriginal species, less -80 adventive and 3 introduced species. The number of differential species identified during the comparison of floras and their proportion in the flora are presented in Table 2.

Table 2. Quantitative indicators of differential species of the studied pine forests.

\begin{tabular}{|l|c|c|c|c|}
\hline \multicolumn{1}{|c|}{ Pine forests } & Usmansky & Khrenovsky & Buzuluksky & Krasnosamarsky \\
\hline Tarameters & $223 / 20.7$ & $48 / 5.6$ & $89 / 11.2$ & $57 / 8.5$ \\
\hline $\begin{array}{l}\text { Aboriginals (among } \\
\text { the aboriginals) }\end{array}$ & $131 / 15.4$ & $37 / 5.3$ & $67 / 9.9$ & $52 / 8.9$ \\
\hline $\begin{array}{l}\text { Adventives (among } \\
\text { the adventives) }\end{array}$ & $81 / 37.5$ & $10 / 7.7$ & $18 / 16.1$ & $4 / 5.0$ \\
\hline $\begin{array}{l}\text { Introduced plants } \\
\text { (among the } \\
\text { introduceds plants) }\end{array}$ & $11 / 91.7$ & $1 / 50.0$ & $4 / 57.1$ & $1 / 33.3$ \\
\hline
\end{tabular}

Note: ${ }^{*} * *$, where $*-$ absolute number, $* *-$ share from all kinds of group

When analyzing the composition and structure of the differential species, it was noted that the character of each of the compared floras is best reflected in the geographical structure of the aboriginal faction.

In the aboriginal fraction of the flora of the Usmansky pine forest, the boreal and boreal-nemoral latitudinal groups contain the largest number of differential species $18.3 \%$ each (Fig. 2A). Here, unlike other pine forests, representatives of the taiga flora are noted - species of the Ericaceae family: Calluna vulgaris (L.) Hull., Ledum palustre L., Oxycoccus palustris Pers., Vaccinium myrtillus L. and V. vitis-idaea L. Less differential species in the forest-steppe and plurizonal groups (13.0\% in each). There are slightly more species in the nemoral group (10.7\%) than in the steppe group $(9.9 \%)$. Further, in descending order, there are groups covering several zones: boreal-nemoralforest-steppe, forest-steppe and steppe, nemoral-forest-steppe and nemoral-forest-steppe and steppe. 
In the Khrenovsky pine forest, located to the south of Usmansky, among the differential species, priority goes to the forest-steppe latitudinal group $24.3 \%$ (Fig. 2B). The steppe group accounts for $19.0 \%$ of all differential species of the native fraction of the flora of this forest. In other latitudinal groups, there are few such species, $10.8 \%$ each in boreal-nemoral, nemoral, nemoral-forest-steppe, foreststeppe, and steppe. The plurizonal group accounts for $8.1 \%$. One representative each in the boreal-nemoral-forest-steppe and boreal latitudinal groups, which is $2.7 \%$ each.

One third of all differential species of the native fraction of the Buzuluksky pine forest falls on the steppe latitudinal group (Fig. 2C). Together with the plurizonal group, the forest-steppe and steppe groups (15.0\% each) are strengthening their positions. The boreal-nemoral group, although not one of the multi-species, makes up $12.0 \%$. There are even fewer species in the boreal-nemoral-forest-steppe $-8.9 \%$. 6\% of the differential species are included in the boreal and nemoral groups. The nemoral-foreststeppe $(4.5 \%)$, nemoral-forest-steppe and steppe (1.5\%) and forest-steppe (1.5\%) groups contain the smallest number of such species.

In the flora of Krasnosamarsky pine forest, all differential species are distributed mainly in two groups - steppe (44.2\%) and forest-steppe and steppe (40.4\%) (Fig. 2D). Several species each belong to the nemoral (5.8\%) and boreal-nemoral (3.8\%) groups. Such species are rare in the boreal, forest-steppe, and plurizonal groups $-1.9 \%$ each.

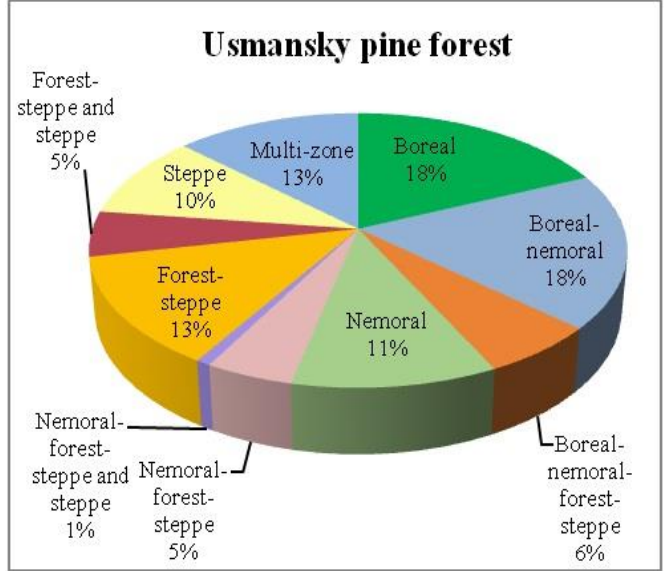

A

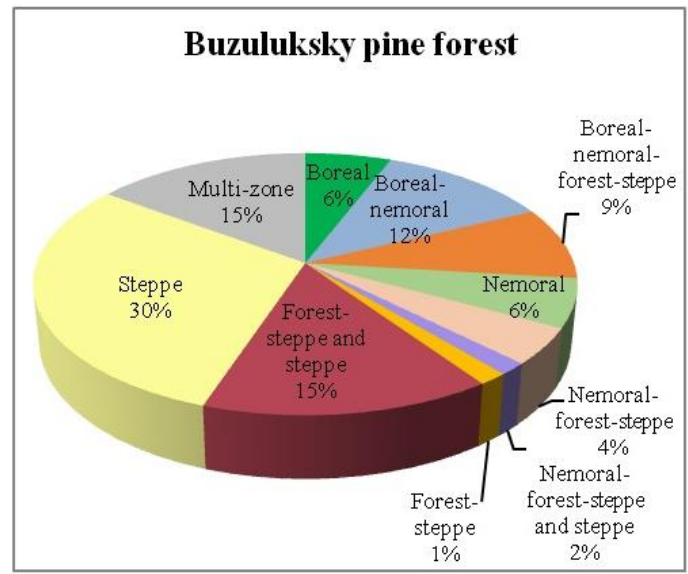

$\mathbf{C}$

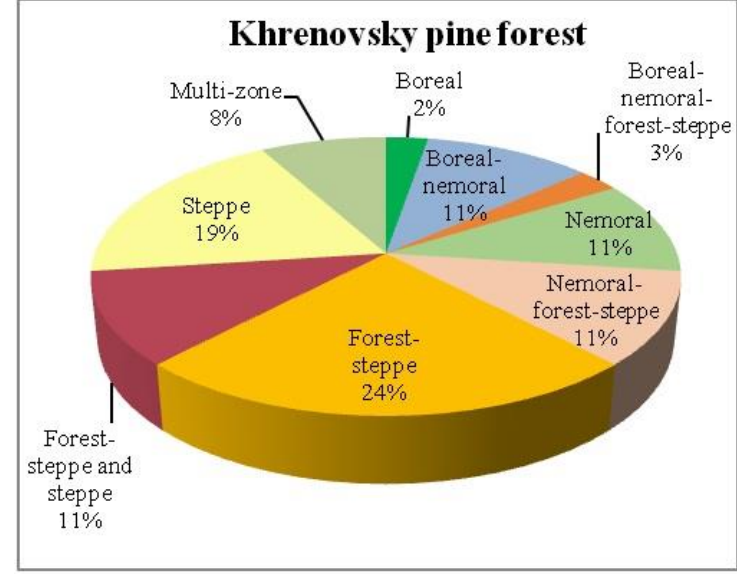

B

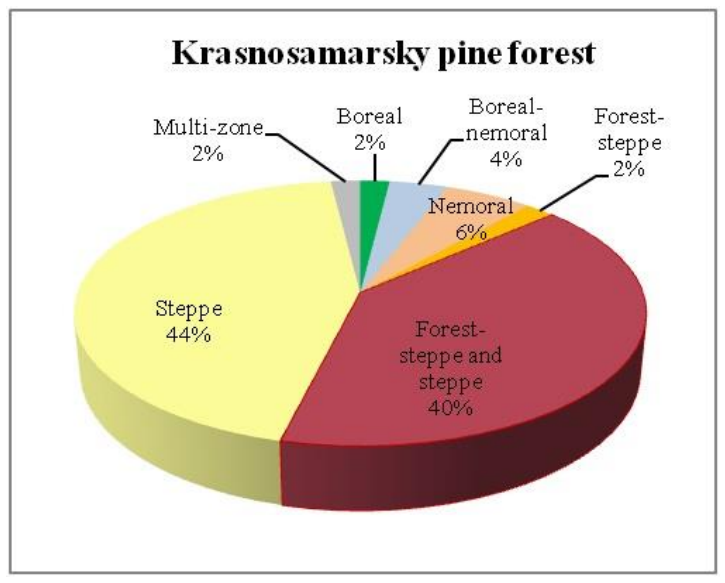

D

Figure 2. The structure of differential species in latitudinal gradient:

A - Usmansky pine forest; B - Khrenovsky pine forest;

C - Buzuluksky pine forest; $\mathbf{D}$ - Krasnosamarsky pine forest. 
In the geographical structure of the longitudinal direction, 74 elements were identified, which were able to be combined into 12 groups (Fig. 3A-D).

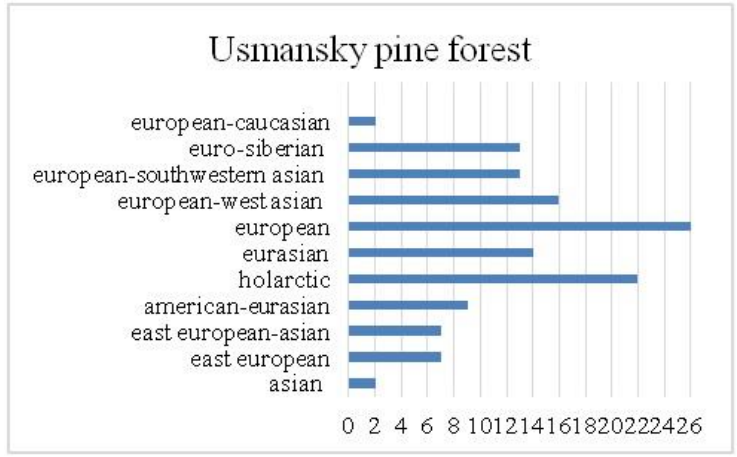

A

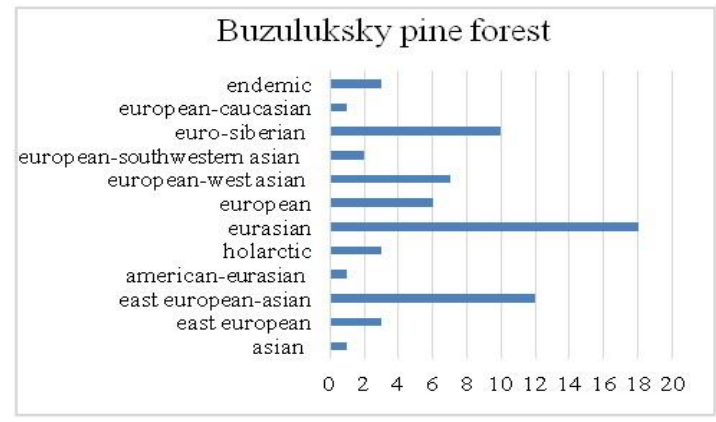

C

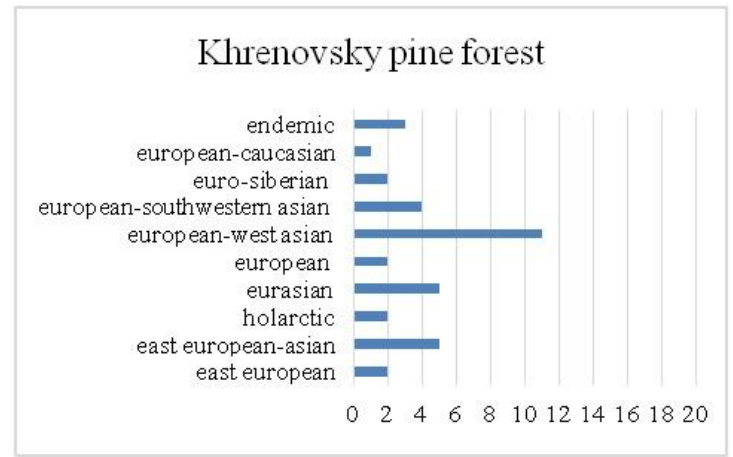

B

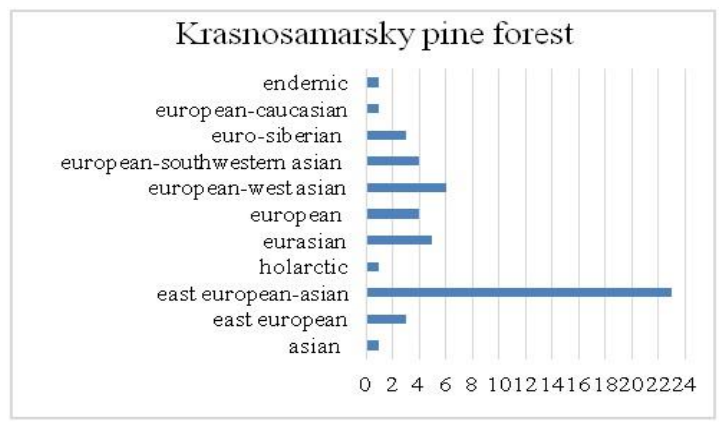

D

Figure 3. The structure of differential species (absolute number) by longitude gradient:

A - Usmansky pine forest; B - Khrenovsky pine forest;

C - Buzuluksky pine forest; $\mathbf{D}$ - Krasnosamarsky pine forest.

In the Usmansky pine forest, the differential species of the aborigine fraction are distributed in 11 longitudinal groups (Fig. 3A). A significant part of these species is with European $(19.1 \%)$ and Holarctic $(16.8 \%)$ distribution, less with European-West Asian (12.2\%) and Eurasian (10.7\%).

In Khrenovsky pine forest, the differential species of the aborigine fraction of the flora are combined in 10 longitudinal groups (Fig. 3B), where the most saturated species are European-West Asian (29.7\%). There are fewer such species in the East EuropeanAsian (13.5\%), Eurasian (13.5\%) and European-Southwestern Asian (10.8\%) groups. 3 endemic species are noted here, 2 of them are east European: the forest-steppe endemic of the river sands Centaurea sophiae Klok. and steppe narrow-localized endemic of pine forest sands $C$. pineticola Iljin. and 1 East European-South Siberian steppe - Festuca wolgensis P. Smirn - is found in the forest on sand in open places.

Differential species of the aborigine fraction of the Buzuluk pine forest are distributed in 12 longitudinal groups (Fig. 3C) with a significant predominance of representatives in the Eurasian (26.9\%) and East European-Asian (17.9\%). There are fewer species with Euro-Siberian (14.9\%) and European-West Asian (10.4\%) ranges. The originality of the flora is given by 3 endemic species found on the territory of the Buzuluksky pine forest: the South Ural nemoral Lathyrus litvinovii Iljin. - in the forest is rare among shrubs along the forest edges; Volga-South Ural mountain-steppe Astragalus wolgensis Bunge. - occupying steppe plots in this forest; Ural subborealmontan Elytrigia reflexiaristata (Nevski) Nevski. - noted here on sandy steppe sites. 
In Krasnosamarsky pine forest, differential species of the aborigine flora fraction are distributed in 11 longitudinal groups (Fig. 3D). Half of these species have an East European (44.2\%) range. The remaining groups are small and contain from 1 to 5 species. The originality of the pine forest flora is given by the South Ural mountainsteppe endemic Dianthus uralensis Korsh. - calling in pine forest by of steppe sandy places.

\section{Conclusion}

The geographic structure of the differential species of the aboriginal flora fraction reflects the floristic features of the studied pine forests. In the forest-steppe forests, despite their territorial proximity, the difference in both latitudinal and longitudinal distribution of differential species is clearly visible. Thus, among the species found only in the Usmansky pine forest, representatives of taiga and taiga-deciduous forests (boreal, boreal-nemoral) with European and Holarctic ranges prevail. $75 \mathrm{~km}$ to the southeast, in the Khrenovsky pine forest, among the species found in the aboriginal fraction of only this of the compared woodlands, most of the representatives of the forest-steppe and steppe latitudinal groups with a European-West Asian range.

There are several reasons for this difference. First, area covered by the forest. Usmansky pine forest has an area almost 2 times larger than Khrenovsky pine forest and, accordingly, the ability to show its internal - forest - boreal-nemoral character, despite the fact that it is located in the forest-steppe zone and is far from the forest zone. Secondly, a part of the territory of Usmansky pine forest is covered by the reserve regime, the negative impact of the anthropogenic factor has been significantly reduced. In contrast to Usmansky pine forest, Khrenovsky, in addition to constant forest felling, experiences a powerful recreational load. The unregulated collection of mushrooms, berries, and medicinal plants also causes significant damage not only to the collection objects themselves, but sometimes to almost complete destruction of unique ecosystems, to the destruction of taxa with a taiga area previously noted in this forest. Third, although the Usmansky and Khrenovsky pine forests are located in the same natural zone, the location of the first one to the northwest of the second directly affects the nature of the geographical structure of the differential species.

The established geographical structure of the differential species of the aborigine fraction of the flora of the studied pine forests allowed us to draw the following conclusion. Differential species of flora of the forest-steppe pine forests of the Oka-Don lowland are represented mainly in the Usmansky pine forest by forest (boreal, borealnemoral and nemoral) taxa with a range both in the Holarctic as a whole and in the European, European-Est-North Asian part of the continent. In Khrenovsky, located $95 \mathrm{~km}$ southeast of the Usmansky pine forest, there are more representatives of the forest-steppe zone. The proportion of nemoral species is also high, with the distribution of habitats to taiga (boreal-nemoral) and forest-steppe (nemoral-forest-steppe) zones. In the longitude direction European-West Asian species are of great importance.

Differential species of the aborigine fraction of the pine forests flora of the steppes of the Trans Volga region, Buzuluksky and Krasnosamarsky, belong mainly to the steppe latitudinal group. The largest share of these species has Eurasian and East European-Asian ranges. It should be noted that in the Krasnosamarsky pine forest, the forest-steppe and steppe groups have an almost equal proportion of the steppe latitudinal group, which is much less pronounced in the Buzuluksky pine forest. This is probably due to the closer location of the former to the forest-steppe zone. 
Thus, the geographical structure of the differential species of the aboriginal fraction of floras makes it possible to clearly trace the features and nature of the floras of the studied pine forests, even taking into account the fact of the relatively close location of forest-steppe and steppe forest pairs.

\section{Acknowledgements}

This work was carried out within the framework of the institute's planned budget topic "Steppes of Russia: landscape-ecological foundations of sustainable development, substantiation of nature-like technologies under natural and anthropogenic environmental changes" No. AAAA-A17-117012610022-5.

\section{References}

Crichfield WB, Little EL (1966) Geographic distribution of the pines of the world. Miscellaneous publication: 991. U.S. Departament of Agriculture, Forest Service, Washington, D.C., 64.

Godnev ED, Zaytsev BD, Miron KF, Nesterov VG, Chardymov NP (1949) Buzulukskiy bor. Tom 1: Obshchiy ocherk i lesnyye kul'tury [Buzuluksky pine forest. Vol. 1: General outline and forest cultures]. Publishing House Goslesbumizdat, MoscowLeningrad, 5-13 [in Russian].

Grigorievskaya AYa, Starodubtseva EA, Khlyzova NYu, Agafonov VA (2004) Adventivnaya flora Voronezhskoy oblasti: istoricheskiy, biogeograficheskiy, ekologicheskiy aspekty [Adventure flora of the Voronezh region: historical, biogeographic, ecological aspects]. Voronezh State University Publishing House, Voronezh, 320 pp. [in Russian].

Kamelin RV (2017) Flora Severa Yevropeyskoy Rossii (v sravnenii s blizlezhashchimi territoriyami) [Flora of the North of European Russia (in comparison with the neighboring territories)]. BBM Publishing House, Saint Petersburg, $241 \mathrm{pp}$. [in Russian].

Kazakova MV, Rzhevuskaya NA, Khlyzova NYu, Aleksandrova KI, Grigorievskaya AYa (1996) Flora Lipetskoy oblasti [Flora of the Lipetsk region]. Argus, Moscow, 352 pp. [in Russian].

Kin NO (2019) The similarity and difference in the flora of the pine forest on the southern border of the range of Pinus sylvestris L. BIO Web of Conferences 16: 00011. https://doi.org/10.1051/bioconf/20191600011.

Korchikov ES, Prokhorova NV, Plaksina TI, Matveev NM, Makarova YuV, Kozlov AI (2010) Floristicheskoye raznoobraziye osobo tsennogo Krasnosamarskogo lesnogo massiva Samarskoy oblasti: 1. Sosudistyye rasteniya [Floristic diversity of the most valuable Krasnosamar forest area of the Samara region: 1. Vascular plants]. Samarskaya Luka: problemy regional'noy i global'noy ekologii [Samarskaya Luka: problems of regional and global ecology] 19 (1): 111-136 [in Russian].

Kulikov PV (2005) Konspekt flory Chelyabinskoy oblasti (sosudistyye rasteniya) [Abstract of the flora of the Chelyabinsk region (vascular plants)]. Geotour, Ekaterinburg-Miass, 537 pp. [in Russian]. 
Kulikov PV, Zolotareva NV, Podgaevskaya EN (2013) Endemichnyye rasteniya Urala vo flore Sverdlovskoy oblasti [Endemic plants of the Urals in the flora of the Sverdlovsk region]. Goshchitsky, Ekaterinburg, 612 pp. [in Russian].

Milkov FN (1977) Prirodnyye zony SSSR [Natural areas of the USSR]. Publishing House Mysl', Moscow, 293 pp. [in Russian].

Saksonov SV, Senator SA (2012) Putevoditel' po Samarskoy flore (1851-2011). Flora Volzhskogo basseyna [A guide to the Samara flora (1851-2011). Flora of the Volga basin]. Kassandra, Tolyatti, 511 pp. [in Russian]. 